\title{
FÉSÜS LÁSZLÓ
}

\section{0 ÉVES A MAGYAR TUDOMÁNYOS AKADÉMIA ÖKOLÓGIAI KUTATÓKÖZPONT BALATONI LIMNOLÓGIAI INTÉZETE}

\author{
Köszöntő beszéd - Elhangzott a Limnológiai Intézetben \\ 2017. szeptember 8-án tartott ünnepi ülésen
}

\begin{abstract}
The Lake Balaton Institute of Limnology of the Ecological Research Centre of the Hungarian ACADEMY OF ARTS AND SCIENCES IS 90 YEARS OLD. The Balaton Limnology Institute of the Hungarian Academy of Arts and Sciences celebrated the $90^{\text {th }}$ anniversary of its opening on the $8^{\text {th }}$ of September, 2017, in Tihany, where László Fésüs, chairman of the Biology Section of the Hungarian Academy of Sciences greeted the event with the address printed here. The institute, originally called "The Hungarian Biology Research Institute" was the very first independent research institution in Hungary, established and opened in 1927 by the famous politician Kúnó Klébelsberg who is also highly respected for developing university campuses and many new elementary schools. During nine decades the institute attracted leading life scientists from Hungary as well as abroad, its research areas covered the major trends in biology including broad topics in botany, zoology, molecular biology, neurobiology and has had a crucial role saving Lake Balaton from ecological catastrophes.
\end{abstract}

A Magyar Tudományos Akadémia Biológiai Tudományok Osztálya örömmel és tisztelettel jött köszönteni és ünnepelni a klebelsbergi örökség emblematikus helyét, a Magyar Biológiai Kutató Intézet mint első önálló magyar kutatóintézet 90 évvel ezelőtti megalapítását, a Magyar Örökségdíj 2017. évi kitüntetettjét.

Osztályunk kivételesen gazdag tudománytörténelmi örökségekben, hiszen a több mint 180 éves Vácrátóti Botanikus Kert, az MTA Ökológiai és Botanikai Intézetének része, 2016-ban szintén Magyar Örökségdíjat kapott. Az MTA Szegedi Biológiai Központ (SZBK) Genetikai Intézetének jogelődje 1939-ben létesült. Az SZBK jövőre ünnepli megnyitásának 45. évét. A jelenlegi MTA Természettudományi Kutató Központ Enzimológiai Intézet jogelődje az 1950-ben létrehozott MTA Biokémiai Intézet.

A limnológiai kutatóintézet nemcsak a kora miatt foglal el speciális helyet osztályunk történetében, hanem azért is, mert ide vezethetjük vissza a Biológiai Tudományok Osztálya interdiszciplinaritását, sokszínűségét.

Az 1926. évi alapkőletétel során többen, így Klebelsberg és Verzár Frigyes (aki 1936-ig szakmai igazgató volt) hangsúlyozták, hogy mivel a „biológia” az állat- és növénytani, a bakteriológiai és az embertani tudományok gyüjtőtudománya, ésszerủbb immár ezt alkalmazni az élettudományok összességére, s így lett a tihanyi intézet neve 
Magyar Biológiai Kutatóintézet. Megjelent tehát a biológia, mint holisztikus definíció az élettudományok egészére. Nem sejtve még (vagy talán mégis) azt a hatalmas fejlödést, amit a biológiai tudományok hoztak - különösen a 20. század második felében, majd napjainkban 21. századi tudományként.

Az 1927. évi megnyitás után a kis létszámú kutatógárda mellett a széles értelemben vett biológia neves vendégkutatói jártak ide dolgozni, közel ezren az első két évtizedben. Ott volt a kezdeteknél Soó Rezső, a modern, funkcionális növényrendszertan későbbi megalkotója, Wolsky Sándor, a nagyhírű evolúcióbiológus, aki osztályunk és az Akadémia eddig legidősebb kort megélt tagja volt. Munkásságukra is alapozódtak a későbbi nagy, jogosan aranykoroknak is nevezett Balaton-kutatási korszakok, amelyeket Entz Géza, Woynarovich Elek, a köztünk lévő Herodek Sándor és Bíró Péter fémjeleztek - beleértve a Balaton megmentésének tanulságos időszakát, amikor az 1965-ös és az 1975-ös tömeges balatoni halpusztulás, és legfőképpen a Balaton vízminőségének drámai romlása miatt újra a hidrobiológia lett a tihanyi intézet fó profilja. Napjainkban pedig megjelenik Tihanyban az elméleti evolúciókutatási program Szatmáry Eörs vezetésével.

A manapság molekuláris élettudományoknak nevezett terület kezdeteihez természetesen a számos alkalommal itt kutató Szentgyörgyi Albert munkásága kötődik, aki igazgatótanácsi tag is volt. Az első aranykor része volt az izomműködés, az ideg-izom kapcsolat fiziológiájának és biokémiájának vizsgálata. Dolgozott itt Győrffy Barna, a korabeli magyar molekuláris genetikai kutatások úttörője is. Farkas Tibor és Herodek Sándor pedig biokémiai indíttatással a nemzetközi limnológiában elsőként világítottak rá arra, hogy a vízi szervezetek, nevezetesen a rákok telítetlen zsírsav aránya hideg időszakban nő, hogy a lipidmembránok viszkozitása megmaradjon. Ezzel indult Farkas Tibor nagy szakmai visszhangot kiváltó pályafutása, ami az SZBK-ban a ma is kiemelkedő eredményeket hozó lipidkutatási iskola munkásságában teljesedett ki. A molekuláris kutatások kapcsolódnak a kémiai ökológia, a környezeti toxikológia tihanyi eredményeihez - amelyről osztályunk 2015-ös legutóbbi látogatásakor kaptunk fontos információkat - és a molekuláris biológiai módszereken alapuló taxonómiai vizsgálatokhoz.

Osztályunk harmadik meghatározó szakmai területe az idegtudomány. Dolgozott Tihanyban Szentágothai János világhírủ agykutatónk, aki később osztályunk elnöke is volt. A hatvanas években Salánki János igazgató vezetése alatt Zsolnai-Nagy Imre, Lábas Elemér, majd Elekes Károly és mások részvételével megjelent markáns kutatási területként a gerinctelen állatok neurobiológiája, ötvözve a szövettani, élettani, biokémiai megközelítéseket. Megalakult itteni székhellyel és vezetéssel az International Society for Invertebrate Neurobiology. Napjainkban pedig itt is van munkacsoportja a kiemelkedő jelentőségű Nemzeti Agyprogramnak.

Kevés olyan helye lehet a magyar felsőoktatásnak és kutatóintézeti világnak, ahol ne lennének a tihanyi intézethez kötődő szálak. Így van ez Debrecennel is, a Debreceni Egyetemen is - amelynek Főépülete sem fejeződhetett volna be Klebelsberg felsőokta- 
tási programja nélkül, de a klinikák sem épültek volna meg. Verzár Frigyes az élettan első professzora volt Debrecenben az egyetem orvoskarának 1918-as megalakulásától kezdve, és ezzel együtt látta el a tihanyi teendőket - 1926-tól már az építkezések kezdetétől, majd mint annak első igazgatója. Soó Rezső korszakos munkássága is Debrecenben teljesedett ki, Hankó Béla és Woynarovich Elek a Debreceni Egyetem Állattani Tanszékére került Tihanyból, az itt korábban kutató kiváló morfológus Krompecher István iskolát teremtett a Debreceni Orvostudományi Egyetem Anatómiai Intézetében. Oroszlán István is itt kezdte pályáját - ő a retrovirális onkogének egyik felfedezője az USA-ban, később a Debreceni Orvostudományi Egyetem díszdoktora lett. Bíró Péter pedig hosszú ideje segíti a debreceni hidrobiológiái oktatást, kutatást.

Tisztel ünnepi ülés!

A Biológiai Tudományok Osztálya nevében ezekkel a gondolatokkal köszöntöm a balatoni Limnológiai Intézetet, annak valamennyi munkatársát, akik továbbviszik az elődök felelősségteljes munkáját. Osztályunk tudja és érzi a felelősséget az intézet jövőjéért, figyel az intézetre, bízik abban, hogy folyamatosan megkapja kutatásaihoz, Balatont őrző-védő munkásságához a méltó támogatást - a nagyon esedékes felújításokhoz is -, és segítik abban, hogy sokat tudjanak tenni a közelmúltban kiemelt kutatási területté vált Nemzeti Víztudományi Kutatási Program sikerérért is. 